\title{
Corrective notice to the European mudminnow (Umbra krameri, Walbaum 1792) record from the Black Sea
}

\author{
Juraj Hajdú ${ }^{1}$, Levente Várkonyi ${ }^{2}$, Ján Ševc ${ }^{1}$, Tamás Müller ${ }^{2 *}$, \\ ${ }^{1}$ Faculty of Humanities and Natural Sciences, University of Prešov, U1. 17. Novembra 1, \\ Prešov, Slovakia, hajdu.juraj@gmail.com \\ ${ }^{2}$ Department of Aquaculture, Institute of Environmental and Landscape Management \\ Faculty of Agriculture and Environmental Science, Szent István University, \\ Páter K. u. 1, 2100 Gödöllö, Hungary, muller.tamas@mkk.szie.hu
}

Abstract

Raykov et al. (2012) recorded the European mudminnow (Umbra krameri) from the Black Sea, at a depth of 36.3-41 m. Morphometric comparison of the pictured specimen with 10 adult $U$. krameri and published data was conducted which excluded its taxonomic affiliation to Umbridae family.

Keywords: morphometric parameters; endangered fish; taxonomic revision, 
Introduction

European mudminnow (Umbra krameri) is an endemic stagnophil species of the Danube and Dniester river drainages (Lelek 1987), inhabiting marshes and lowland waters densely overgrown by aquatic vegetation (Wilhelm 2003, Pekárik et al. 2014). The species is threatened by extinction in many of its original habitats (Simić et al. 2007). According to IUCN Red List it is categorized as "Vulnerable" since its isolated and decrescent populations are estimated to have declined by more than $30 \%$ in the past 10 years (Freyhof 2011). Raykov et al. (2012) reported the first record of U. krameri in Romanian territorial waters of the Black Sea, in south-eastern direction from the mouth of the Sfântu Gheorghe Danube River arm at the 36.3-41 meters of depth. According to authors' results the genetic markers found after analyses of one non-enzymatic and six enzymatic systems encoded by totally 18 loci could be used for the species identification. The authors provided the picture of the captured species that differed anatomically from the European mudminnow (see Figure 1). According to this observation Yankova et al. (2013) cited this fish species as non-invasive for the Black Sea. The aim of this study was to demonstrate the morphometric distinction of the specimen reported by Raykov et al. (2012) from the test sample of $U$. krameri originating from native freshwater populations, considering also the available literature data (Berinkey 1966, Wanzenböck 1996).

Material and methods

The fish specimen described from the Black Sea by Raykov et al. (2012) as U. krameri was the object of our morphometric investigation (Fig. 1). Test sample consisted of 10 adult individuals of U. krameri originating from native freshwater populations (Müller et al. 2011, Bajomi et al. 
2013). Altogether 11 external morphometric parameters (Fig. 2, Table 1) measured according to Specziár et al. (2009) recalculated in \% of Standard length (Holčík and Hensel 1972) were used for comparative analysis. Since the European mudminnow is strictly protected, all morphometric treatments were conducted according to photographs using ImageJ software (Rasband 2012). Each measurement was taken as the shortest (direct) distance between two corresponding reference points. Dixon's Q-test was used for detection of outliers in data sets consisting of related parameters of the Black Sea specimen and the test sample originating from freshwater populations (Dixon and Massey 1969).

Results and discussion

According to our morphometric treatment significant differences were found for the specimen described from the Black Sea by Raykov et al. (2012) compared to the test sample of $U$. krameri originating from native freshwater populations. According to Dixon's Q-test the Black Sea specimen (Fig. 1) differed significantly from the freshwater sample in 8 parameters that proved to be significant outliers within data sets at the significance level of $5 \%$ (Table 1 , Fig. 2). Furthermore, five parameters proved to be outliers at the significance level of $1 \%$ (Table 1). The most apparent differences $(\mathrm{p}<0.01)$ were found in ratios of PEVD, PVD, LD, VAD and MAXH, followed by PDD, CP and PHL (Table 1) which proved to be significant as well $(\mathrm{p}<0.01)$. Apart from this, there is some obvious differences of the described specimen from U. krameri; for instance pectoral fins of the European mudminnow originate near the bottom of abdomen in equal horizontal line to its ventral fins (Fig. 2). Contrary to this, the ventral fins of the published species are situated well forward and almost beneath the pectoral fins (thoracic position), that is a typical feature of Perciformes (Fig. 1). Moreover, several additional morphological features show that the species discovered by Raykov et al. (2012) 
does not belong to the genus Umbra (Umbridae, Esociformes). In case of $U$. krameri a single dorsal fin is situated in the second half of the body (Wanzenböck 1996) and originates directly above the origin of the pelvic fins (Fig. 2). In contrast to this, there is a double dorsal fin of the published species situated in the median line of the body, originating behind the base of the pelvic fins (Fig. 1). The presence of the teeth on the operculum of the Black Sea specimen (Fig. 1) is a morphological feature characteristic for Perciformes which is never present in Umbridae.

\section{Conclusion}

Based on our morphometric comparison, serious misidentification can be stated for the species described from the Black Sea by Raykov et al. (2012). This specimen differed significantly from the $U$. krameri in 8 examined parameters (Table 1). Since the European mudminnow requires very specific habitat (Pekárik et al. 2014) the probability of its occurrence in such extreme environment as described by Raykov et al. (2012) is very low. Although the size and condition of the examined sample did not allow more precise determination of the species, several morphometric features of the Black sea specimen suggest its taxonomic affiliation to the order Perciformes.

\section{Acknowledgements:}

The research has been supported by Bolyai János research grant (BO 54/12/4) and Research Centre of Excellence-9878/2015/FEKUT and by the agency of Ministry of Education, Science, Research and Sport of the Slovak republic, the project ITMS: 26110230119. 


\section{References}

Bajomi B., Tatár S., Tóth B., Demény F., Müllerné T.M., Urbányi B., Müller T. 2013. Captive-breeding, re-introduction and supplementation of European Mudminnow in Hungary, pp. 15-20. In: Soorae P. S. (ed.), Global re-introduction perspectives. Re-introduction casestudies from around the globe IUCN/SSC Re-introduction Specialist Group. Abu Dhabi, United Arab Emirates.

Berinkey L. 1966. Halak - Pisces. Magyarország állatvilága (Fauna Hungariae)[Fishes Pisces. Hungarian fauna]. Vol. XX/2, Akadémia Kiadó, Budapest, 32-33..

Dixon W.J., Massey F.J. 1969. Introduction to statistical analysis. Mc Graw-Hill Company Inc, New York.

Freyhof J. 2011. Umbra krameri. In: IUCN 2012. IUCN Red List of Threatened Species. Version 2012.2. http://www.iucnredlist.org/ (accessed 31.12.2014).

Holčík J., Hensel K. 1972. Ichtyologická príručka [Handbook of ichthyology]. Obzor, Bratislava, Slovakia, 1-217.

Lelek, A., 1987: The Freshwater fishes of Europe. Vol 9. Threatened fishes of Europe. AULA-Verlag Wiesbaden.

Müller T., Balovan B., Tatár S., Müllerné-Trenovszki M., Urbányi B., Demény F. 2011.Lápi póc (Umbra krameri) szaporítása és nevelése a természetesvízi állományok fenntartása és megerősítése érdekében.. Pisces Hungarici 5: 15-20. 
Pekárik L., Hajdú J., Koščo, J. 2014. Identifying the key habitat characteristics of threatened

European mudminnow (Umbra krameri, Walbaum 1792). Fundam. Appl. Limnol. 184 (2): $151-159$. http://imagej.nih.gov/ij/ (accessed 30.6.2014)

Rasband W.S. 2012. ImageJ, U.S. National Institutes of Health, Bethesda, Maryland, USA.

Simić V., Simić S., Paunović M., Cakić, P. 2007. Model of the assessment of the critical risk of extinction and the priorities of protection of endangered aquatic species at the national level. Biodiversity Conservation 16: 2471-2493.

Specziár A., Bercsényi M., Müller T. 2009. Morphological characteristics of hybrid pikeperch (Sander lucioperca female $\times$ Sander volgensis male) (Osteichthyes, Percidae). Acta Zoologica Academiae Scientiarum Hungaricae 55 (1): 37-52.

Raykov V., Panayotova M., Ivanova P., Dobrovolov I., Maximov V. 2012. First record and allozyme data of European mudminnow Umbra krameri Walbaum, 1792 (Pisces: Umbridae) in the Black Sea. Comptes rendus de l'Academie bulgare des Sciences 65 (1): 49-52.

Wanzenböck J. 1996. Workshop II. Conversation of European mudminnow, Umbra krameri, pp. 339-340. In.: Kirchhofer A., Hefti D. (eds.), Conservation of endangered freshwater fish in Europe. Birkhäuser, Basel, Boston, Berlin. 
152 Wilhelm A. 2003. Growth of the mudminnow (Umbra krameri Walbaum) in river Ér. Tiscia,

153 34: $57-60$.

154

Yankova M., Pavlov D., Ivanova P., Karpova E., Boltachev A., Bat L., Oral M., Mgeladze M. 156 2013. Annoted checklist of the non native fish species (Pisces) of the Black Sea. J. Black 157 Sea/Medditerranean Environment 19 (2): 247-255.

158

159 


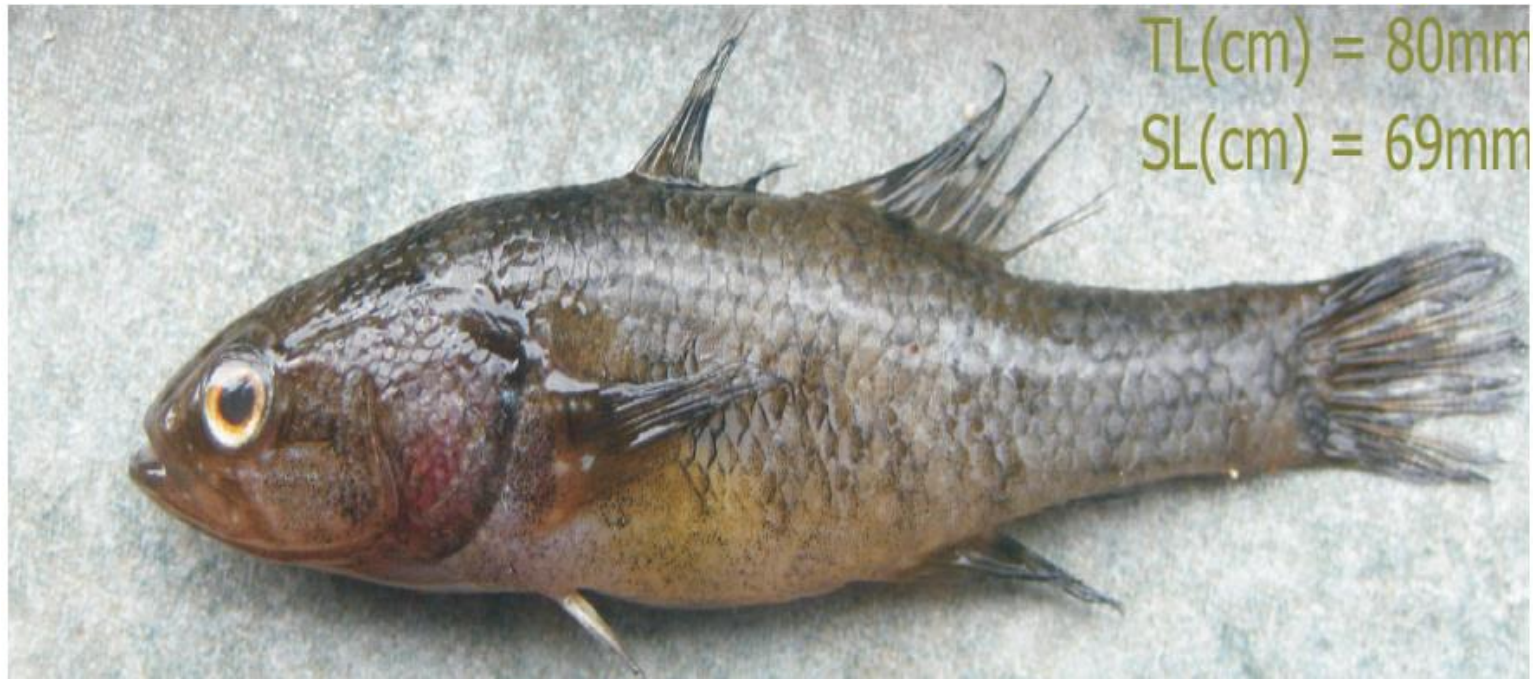

Figure 1. The specimen from the Black Sea published by Raykov et al. (2012).

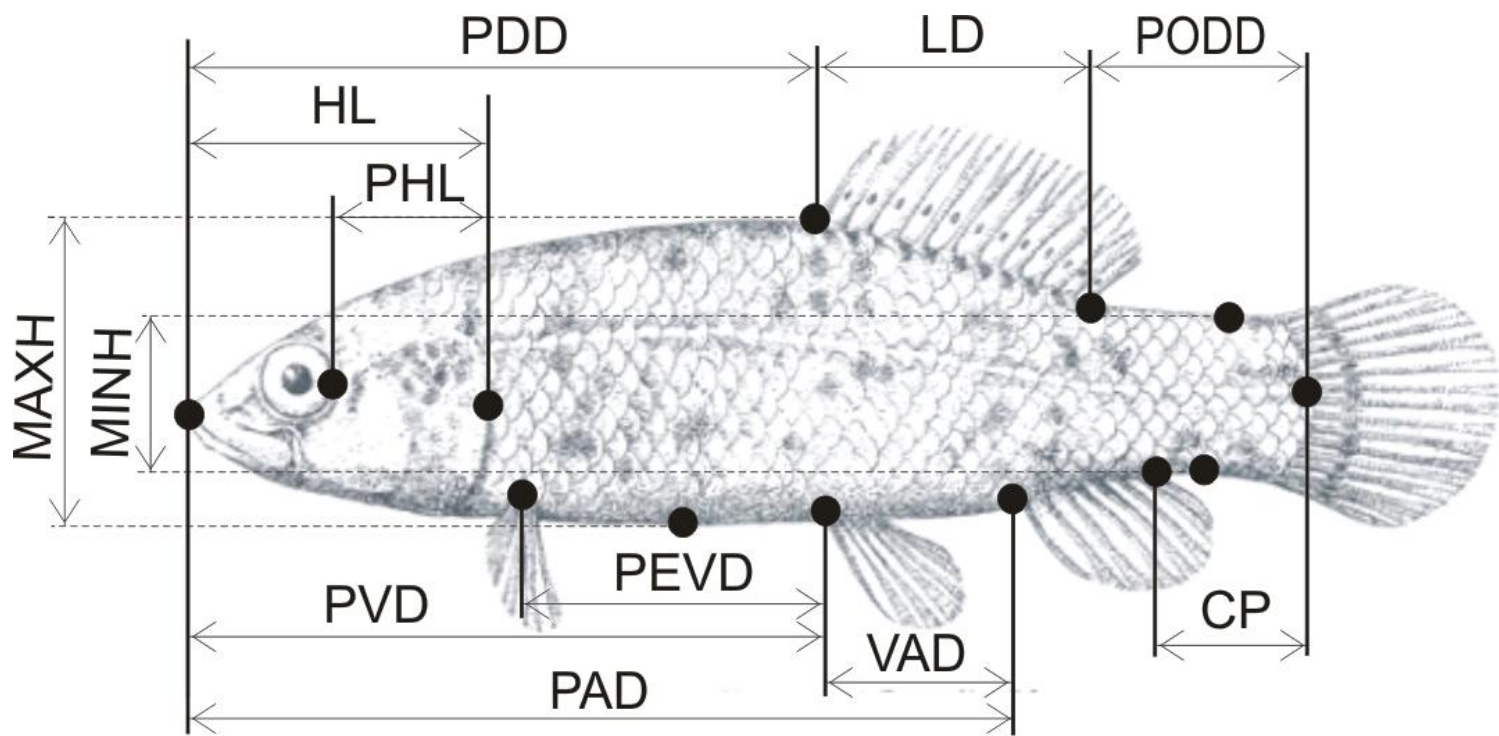

Figure 2. Morphometric parameters used for the analysis. Full names of parameters are given in Table 1. Background picture according to Berinkey (1966). 
Table 1. Comparison of morphometric data and results of the comparative analysis. * Parameters proved to be significant.

\begin{tabular}{|c|c|c|c|c|c|}
\hline \multirow[t]{2}{*}{ Abbrev. } & \multirow{2}{*}{$\begin{array}{l}\text { Measured } \\
\text { parameter }\end{array}$} & \multirow{2}{*}{$\begin{array}{l}\text { Black sea } \\
\text { specimen }\end{array}$} & \multirow{2}{*}{$\begin{array}{l}\text { U. krameri } \\
\text { freshwater }\end{array}$} & \multicolumn{2}{|c|}{ Dixon’s Q-test } \\
\hline & & & & $p<0.05$ & $p<0.01$ \\
\hline SL & Standard length $(\mathrm{mm})$ & 69 & $57.5 \pm 5.1$ & - & - \\
\hline $\mathrm{TL}$ & Total length (mm) & 80 & $71.1 \pm 6.2$ & - & - \\
\hline PDD & Predorsal distance & 42.8 & $52.2 \pm 2.9$ & * & \\
\hline PAD & Preanal distance & 61.9 & $68.2 \pm 1.9$ & & \\
\hline PVD & Preventral distance & 33.8 & $53.8 \pm 1.4$ & $*$ & $*$ \\
\hline PEVD & $\begin{array}{l}\text { Distance between pectoral } \\
\text { and ventral fins }\end{array}$ & 2.4 & $21.0 \pm 1.6$ & $*$ & $*$ \\
\hline LD & Length of dorsal fin base & 30.4 & $24.6 \pm 1.0$ & $*$ & $*$ \\
\hline VAD & Ventral-anal fin distance & 27.6 & $15.6 \pm 1.8$ & $*$ & $*$ \\
\hline $\mathrm{CP}$ & Length of caudal peduncle & 28 & $17.3 \pm 2.6$ & $*$ & \\
\hline PODD & Postdorsal distance & 26.3 & $19.6 \pm 2.2$ & & \\
\hline HL & Head length & 33.1 & $29.6 \pm 2.0$ & & \\
\hline MAXH & Maximum body height & 35.4 & $24.4 \pm 1.3$ & $*$ & $*$ \\
\hline MINH & Minimum body height & 14.8 & $13.3 \pm 0.5$ & & \\
\hline PHL & Postorbital head length & 20.6 & $16.3 \pm 1.2$ & $*$ & \\
\hline
\end{tabular}

